\title{
Reliability of Microbiological Tests in the Diagnosis of Clostridium Difficile Infection
}

\author{
Predrag Stojanović1,2, Niko Radulović3 , Branislava Kocić1, Marina Dinić1,2, \\ Biljana Miljković Selimović1 ${ }^{1}$ Kristina Stojanović ${ }^{1}$ \\ ${ }^{1}$ University of Niš, Faculty of Medicine, Niš, Serbia \\ ${ }^{2}$ Public Health Institute Niš, Center of Microbiology, National Reference Laboratory for Anaerobic \\ Infections-Clostridium difficile, Niš, Serbia \\ ${ }^{3}$ University of Niš, Faculty of Science and Mathematics, Department of Chemistry, Niš, Serbia
}

\section{SUMMARY}

The aim of the study was to analyze the characteristics \{sensitivity, specificity, positive predictive value (PPV), negative predictive value (NPV) and credibility\} of tests for microbiological diagnosis of infections caused by Clostridium (C. difficile).

The research was done at the Public Health InstituteNiš, the Center for Microbiology during the period 2016-2019. The study included 25 patients with Clostridium difficile infection (CDI) ( 25 fecal samples) and 50 patients with diarrhea who were not diagnosed with CDI (50 faecal samples). The samples were examined by various tests for the detection of toxin in the stool and with two tests to prove the produced glutamate dehydrogenase enzyme GDH. RIDA GENE Clostridium difficile test (Real Time Multiplex PCR, R-Biofarm, Damstadt, Germany) was used as a reference test.

Among the examined tests, the highest sensitivity in toxin detection was the ELISA-ridascreen $C$. difficile Toxin A / B (R - Biopharm AG, Darmstadt, Germany) $(88 \%$, PPV $=85.71 \%, \mathrm{NPV}=97.87 \%)$ and the lowest $C$. difficile TOXIN A\& B - CHEK-1 (VEDALAB, ALENCON CEDEX, France) $(68 \%$, PPV = 85\%, NPV = 85.45\%). All toxin detection tests had a high specificity that was not less than $92 \%$. In detecting the GDH antigen, the Rida ${ }^{\circledR}$ QUICK C. difficile GDH test ( $\mathrm{R}$ - Biopharm AG, Darmstadt, Germany) showed better performance (sensitivity $100 \%$, specificity $92 \%$, PPV $=89.28 \%$, NPV $=100 \%$ and authenticity $94.66 \%$ ).

The results of the research conducted in Niš showed high values of the characteristics for certain toxindetecting tests in feces (sensitivity up to $88 \%$, specificity to $98 \%$, etc.). Research results in other studieshave shown that the values of the parameters that determine the characteristics of the tests are lower by $10 \%-20 \%$, although there is a study whose results are consistent with ours. The reasons for relatively high values should be sought in strict selection criteria for samples that are close to criteria present in factory conditions when designing such tests. 
Although the results of this study confirm that there is no ideal diagnostic test in the microbiological diagnosis of CDI, the high sensitivity, specificity, PPV and NPV values make GDH tests suitable for the first screening of sample stools in everyday work.

Key words: Clostridium difficile, toxin, glutamate dehydrogenase (GDH), microbiological diagnosis

Corresponding author:

Predrag Stojanović

E mail: pedjamicro@sezampro.rs 


\section{INTRODUCTION}

Clostridium difficile (C. difficile) is the leading cause of infectious diarrhea in hospitalized patients $(C$. difficile associated disease - CDAD; $C$. difficile infetion - CDI is more commonly used today). A particular microbiological, epidemiological and clinical challenge is the spread of hypervirulent strains that cause severe disease in immunocompetent patients who have not previously taken antibiotics (1). Diagnosis of CDI is set by various clinical and microbiological methods whose reliability has variations in sensitivity and specificity (molecular methods, immunochromatographic tests, toxins A and B immunoassays, cytotoxicity test on cell culture, etc.) (1, 2). Detection of toxins significant in pathogenesis of the disease is a key part in the diagnosis of CDI. A cytotoxicity test on cell culture proving the production of toxin B is considered to be the "gold standard", but many studies over the last ten years point to its disadvantages (eg possible lower sensitivity compared to cultivation). The technical complexity, costs and long incubation period of up to $48 \mathrm{~h}$, the gold standard, led to the need to speed up rapid tests that yield results in ten minutes or up to 2 hours. Research conducted over the last 5 years has shown that the application of the PCR method successfully replaces the "gold standard" $(2,3)$. Due to the speed of obtaining results in everyday work, commercial enzyme immunoassays (ELISA) or immunochromatographic tests for stool toxin detection or glutamate dehydrogenase - GDH are used. During 2008, $95 \%$ of laboratories reported using immunoassay or immunochromatographic tests for the detection of $C$. difficile toxin. All immunoassays were validated by comparison with the "gold standard" in the factory conditions, where the sensitivity and specificity of the tests (immunochromatographic and ELISA) were very high (up to $98 \%$ ). However, research shows that in daily work, most immunochromatographic tests for toxin detection have low sensitivity and specificity (up to $80 \%$ ). ELISA tests have better sensitivity (up to $90 \%$ ) (24). The variety of tests used point to the need to establish reliability in everyday work, especially if they are recommended as screening tests.

\section{AIMS}

The aim of the study was to examine the characteristics (sensitivity, specificity, positive predictive value (PPV), negative predictive value (NPV) and credibility) of tests for microbiological diagnostics of $C$. difficile used in the National Reference Laboratory for Anaerobic Infections - Clostridium difficile.

\section{MATERIALS AND METHODS}

The research was done at the Public Health Institute Niš, the Center for Microbiology, the Reference Laboratory for Anaerobic Infections - Clostridium difficile during the period 2016-2019. The study included 25 patients with CDI ( 25 fecal samples) and 50 patients with diarrhea who were not diagnosed with CDI (50 fecal samples).

Daily lab reports (lab list and protocols) about isolation of pathogens in microbiological laboratories and medical documentation (histories of disease, temperature lists) were used as source data.

Standard microbiological procedure was applied during bacteriological examination of stool samples. Stool samples were inoculated on nutrient selective media cycloserine-cefoxitin-fructose agar (CCFA) (Biomedics, Pargqetehnicologico, Madrid, Spain) for $C$. difficile cultivation after alcohol-shock procedure application.

$\mathrm{CCF}$ agar was incubated at $37^{\circ} \mathrm{C}$ under anaerobic conditions for 48 h.AnaeroGen sachets (OXOID, England) were used to anaerobic condition in jars. Anaerobic strips (Anaerobic indicator, OXOID, England) were used to verify anaerobic conditions. Commercial API system for anaerobic bacteria (API 20A BioMerieux, France) was applied for biochemical identification of $C$. difficile isolates (typical colonies were $4 \mathrm{~mm}$ or larger in diameter, elevated, convex, with a discrete margin, an irregular surface and strong horse manure-like odor).

The following tests (according to the manufacturer's instructions) were used to determine the presence of $C$. difficile toxins in fecal samples:

1. MINIVIDAS Clostridium difficile Toxin A/B test (BioMerieux, ME, France).

2. ColorPAC Toxin A test (Becton Dickinson, USA) for C. difficile toxine A.

3. Clostridium difficile Toxin $\mathrm{A} / \mathrm{B}$ ( $\mathrm{R}$ - Biopharm AG, Darmstadt, Germany).

4. Clostridium difficile TOXIN A\& B - CHEK - 1 (VEDALAB, ALENCON CEDEX, France).

5. ImmunoCard ${ }^{\circledR}$ Clostridium difficile TOXIN A\& B (Meridian Bioscience. Inc., Cincinnati, USA).

6. ELISA-ridascreen Clostridium difficile Toxin A/B (R - Biopharm AG, Darmstadt, Germany).

In order to determine the presence of antigen (glutamate dehydrogenase-GDH) C. difficile in the fecal samples, the following tests (according to the manufacturer's instructions) were used: 
1. Culture CDT Rapid Latex Test Kit (BectonDickinson, USA), which detects antigen of $C$. difficile.

2. Rida ${ }^{\circledR} \mathrm{QUICK}$ Clostridium difficile GDH (R Biopharm AG, Darmstadt, Germany).

For in vitro diagnostics of CDI, RIDA GENE Clostridium difficile test was used (Real time multiplex PCR, R-Biofarm, Damstadt, Germany) for the direct, qualitative detection of $C$. difficile (16s-r DNA) and $C$. difficile toxin $\mathrm{A}(\mathrm{tcd} \mathrm{A})$ and toxin $\mathrm{B}(\mathrm{tcdB})$ genes from human stool samples and bacterial cultures.

\section{Definitions}

Diagnosis of CDI was based on the presence of the following criteria (3):

- Diarrheal stools or toxic megacolon, and a positive laboratory assay for $C$. difficile toxin A and/or toxin $B$ in stools or a toxin-producing $C$. difficile detected in stool via culture or other means.

- The presence of pseudomembranous colitis was determined at least by the use of gastrointestinal endoscopic methods.

- The presence of a histopathological finding on a sample of the colon characteristic of infection C. difficile (with or without diarrhea) obtained by endoscopy, colectomy, or autopsy.

A positive finding of $C$. difficile toxin in this study meant a positive finding confirmed by PCR test (tcdA, $\mathrm{tcdB}$ ) and at least three of the six previously mentioned tests in the same stool sample.

A negative finding of $C$. difficile toxin in this study meant a negative finding confirmed by PCR test (tcdA, $\mathrm{tcdB}$ ) and at least three of the six previously mentioned tests in the same stool sample.

A positive finding of the antigen (glutamate dehydrogenase-GDH) of $C$. difficile in this study included the isolated colony of $C$. difficile on the CCFA medium, a positive finding by the PCR test (16s-r DNA) and at least one positive finding of the two aforementioned assays.

The negative finding of antigen (glutamate dehydrogenase-GDH) C. difficile in this study included a negative finding by PCR test (16s-r DNA), at least one negative finding from the two previously mentioned tests and the absence of colony growth on the CCFA medium.

During the research, the following characteristics of the used tests were checked:

1.SENSITIVITY - accurate positive finding for a person with CDI according to the formula:exactpositive / (false negative + exact positive); $\mathrm{EP} /(\mathrm{FN}+\mathrm{EP})$.

2.SPECIFICITY - accurate negative finding in a person who does not have CDI according to the formula: exact negative / (false positive + exact negative); EN/(FP $+\mathrm{EN})$.

\section{PRECISION VALUE OF POSITIVE RESULT} (PPV) or proportions accurately diagnosed in relation to all positive results according to the formula: exact positive / (false positive + exact positive); EP/(FP + EP).

4.PRECISION VALUE OF NEGATIVE RESULTS (NPV) or ratio of exact negative results in relation to all negative results according to the formula: $\mathrm{EN} /(\mathrm{FN}+\mathrm{EN})$.

5.CREDIBILITY - matching the obtained values with the actual state in the population according to the formula: (exact positive + exact negative) / (exact positive + exact negative + false positive + false negative); $(\mathrm{EP}+$ $\mathrm{EN}) /(\mathrm{EP}+\mathrm{EN}+\mathrm{FP}+\mathrm{FN})$.

\section{RESULTS}

During the study, 25 CDI patients (52\% of men, $48 \%$ of women) and 50 patients with diarrhea without CDAD diagnosis were examined ( $54 \%$ of men, $46 \%$ of women).

In patients with CDI, in $23(92 \%)$ cases, the disease was caused by $\mathrm{A}+\mathrm{B}+$ strains and in $2(8 \%)$ cases of A-B + strain of $C$. difficile.

Table 1 shows the results of patients' samples with and without CDI for the presence of toxin and common GDH antigen (Table 1).

The characteristics of the microbiological test (sensitivity, specificity, PPV, NPV, credibility) are shown in Table 2.

Among the examined tests, the highest sensitivity in toxin detection was the ELISA-Ridascreen $C$. difficile Toxin A/B (R- Biopharm AG, Darmstadt, Germany) $(96 \%$, PPV $=85.71 \%, \mathrm{NPV}=97.87 \%)$ and the lowest $C$. difficile TOXIN A \& B - CHEK-1 (VEDALAB, ALENCON CEDEX, France) $(68 \%, \mathrm{PPV}=85 \%, \mathrm{NPV}=$ $85.45 \%)$.All toxin detection tests had a high specificity that was not less than $92 \%$. Among the tests for toxin detection, Rida ${ }^{\circledR} \mathrm{QUICK}$ C. difficile Toxin A/B ( $\mathrm{R}$ Biopharm AG, Darmstadt, Germany) had the highest credibility (96\%).

In detecting the GDH antigen, the Rida ${ }^{\circledR}$ QUICK C. difficile GDH test ( $\mathrm{R}$ - Biopharm AG, Darmstadt, Germany) showed better performance (sensitivity $100 \%$, specificity $92 \%, \mathrm{PPV}=89.28 \%, \mathrm{NPV}=100 \%$ and authenticity $94.66 \%$ ) (Table 2). 
Table 1. Results of examination of patients' stool samples for the presence of toxins and glutamate dehydrogenase (GDH) $C$. difficile

\begin{tabular}{|c|c|c|c|c|}
\hline \multirow[t]{2}{*}{ Microbiological test } & \multicolumn{2}{|c|}{ Positive finding } & \multicolumn{2}{|c|}{ Negative finding } \\
\hline & exactly & false & exactly & false \\
\hline & $\mathrm{n}$ & $\mathrm{n}$ & $\mathrm{n}$ & $\mathrm{n}$ \\
\hline $\begin{array}{l}\text { MINIVIDAS C. difficileToxin A/B test (BioMerieux, } \\
\text { France) }\end{array}$ & 20 & 2 & 48 & 5 \\
\hline $\begin{array}{l}\text { ColorPAC Toxin A C. difficile test (Becton Dickinson, } \\
\text { USA) }\end{array}$ & 19 & 2 & 48 & 6 \\
\hline $\begin{array}{l}\text { Rida }{ }^{\circledR} \text { QUICK C. difficile Toxin A/B (R - Biopharm AG, } \\
\text { Darmstadt, Germany). }\end{array}$ & 22 & 1 & 49 & 3 \\
\hline $\begin{array}{l}\text { C. difficileTOXIN A\&B - CHEK - } 1 \text { (VEDALAB, } \\
\text { ALENCON CEDEX, France) }\end{array}$ & 17 & 3 & 47 & 8 \\
\hline $\begin{array}{l}\text { ImmunoCard }{ }^{\circledR} C . \quad \text { difficileTOXIN } \\
\text { Bioscience. Inc., Cincinnati, USA) }\end{array}$ & 22 & 2 & 48 & 3 \\
\hline $\begin{array}{l}\text { ELISA-Ridascreen C. difficile Toxin A/B (R - Biopharm } \\
\text { AG, Darmstadt, Germany) }\end{array}$ & 22 & 4 & 46 & 3 \\
\hline $\begin{array}{l}\text { CultureCDTRapidLatexTestKit(BectonDickinson,USA) } \\
\text { C.difficile }\end{array}$ & 20 & 5 & 45 & 5 \\
\hline $\begin{array}{l}\text { Rida }{ }^{\circledR} \text { QUICK C. difficile GDH (R - Biopharm AG, } \\
\text { Darmstadt, Germany) }\end{array}$ & 25 & 4 & 46 & 0 \\
\hline $\begin{array}{l}\text { RIDA GENE Clostridium difficile test (Real time } \\
\text { multiplex PCR, R-Biofarm, Damstadt, Germany) }\end{array}$ & 25 & 0 & 50 & 0 \\
\hline
\end{tabular}

\section{DISCUSSION}

Cytotoxicity testing on cell culture is a "gold standard" for the detection of toxin B C. difficile in stool samples due to good sensitivity $(<1$ pg of toxin $B)$ and specificity (neutralization of cytopathogenic effect by specific antiserum to C. sordellia toxins). Sensitivity (usually up to $90 \%$ ) of the "gold standard" must be taken with caution because of the sensitivity of toxin B to protease degradation present in the stool (5).
It has also been established that false positives are possible, because $C$. sordellii produces two exotoxins - LT and HT, which are not associated with diarrheal disease, but may give damage to the culture cells of the "gold standard" (6).

The sensitivity of the "gold standard" can be increased to $98 \%$ if combined with the cultivation and determination of toxin production in the liquid culture of the isolate, resulting in higher costs and a longer time interval ( $24 \mathrm{~h}$ to 4 days) to finally diagnosed CDI $(6,7)$. 
Table 2. Characteristics of the examined tests used in the CDI diagnostics

\begin{tabular}{|c|c|c|c|c|c|}
\hline Microbiological test & $\begin{array}{c}\text { Sensitivity } \\
\%\end{array}$ & $\begin{array}{c}\text { Specificity } \\
\%\end{array}$ & $\begin{array}{c}\text { PPV } \\
\%\end{array}$ & $\begin{array}{c}\text { NPV } \\
\%\end{array}$ & $\begin{array}{c}\text { Credibility } \\
\%\end{array}$ \\
\hline $\begin{array}{l}\text { MINIVIDAS C. difficile Toxin } \mathrm{A} / \mathrm{B} \text { test (BioMerieux, } \\
\text { France) }\end{array}$ & 80 & 96 & 90.90 & 90.56 & 90.66 \\
\hline $\begin{array}{l}\text { ColorPAC Toxin A C. difficile test (Becton Dickinson, } \\
\text { USA) }\end{array}$ & 76 & 96 & 90.47 & 88.88 & 89.33 \\
\hline $\begin{array}{l}\text { Rida }{ }^{\circledR} \text { QUICK C. difficile Toxin A/B (R-Biopharm AG, } \\
\text { Darmstadt, Germany). }\end{array}$ & 88 & 98 & 95.65 & 94.23 & 94.66 \\
\hline $\begin{array}{l}\text { C. difficile TOXIN A\&B - CHEK-1 (VEDALAB, } \\
\text { ALENCON CEDEX, France) }\end{array}$ & 68 & 94 & 85.00 & 85.45 & 85.33 \\
\hline $\begin{array}{l}\text { ImmunoCard }{ }^{\circledR} \text { C. Difficile TOXIN A\&B (Meridian } \\
\text { Bioscience. Inc., Cincinnati, USA) }\end{array}$ & 88 & 96 & 91.66 & 94.11 & 93.33 \\
\hline $\begin{array}{l}\text { ELISA-Ridascreen C. difficile Toxin A/B (R- Biopharm } \\
\text { AG, Darmstadt, Germany) }\end{array}$ & 88 & 92 & 84.61 & 93.87 & 90.66 \\
\hline $\begin{array}{l}\text { CultureCDTRapidLatexTestKit(BectonDickinson,USA) } \\
\text { C.difficile }\end{array}$ & 80 & 90 & 80 & 90 & 86.66 \\
\hline $\begin{array}{l}\text { Rida }{ }^{\circledR} \text { QUICK C. difficile GDH (R-Biopharm AG, } \\
\text { Darmstadt, Germany) }\end{array}$ & 100 & 92 & 89.28 & 100 & 94.66 \\
\hline $\begin{array}{l}\text { RIDA GENE Clostridium difficile test (Real time } \\
\text { multiplex PCR, R-Biofarm, Damstadt, Germany) }\end{array}$ & 100 & 100 & 100 & 100 & 100 \\
\hline
\end{tabular}

If the "golden standard" was combined only with cultivation, it would not be possible to precisely detach toxigenic from non-toxigenic isolates, resulting in a fall in specificity below $98 \%$. For the same reasons, it is recommended to check the production of toxins in liquid culture if the laboratories only cultivate $C$. difficile on a selective medium. In spite of deficiency, cultivation remains a method that must always be applied in epidemiological and other fundamental research (PCR, ribotyping, antibiogram, etc.) (8). Researchers point out that the PCR method can also provide a larger number of accurate positive findings than a cytotoxicity test, which shows that different PCR methods successfully replace cultivation and the "gold standard" in the CDI diagnostics (5). The results of the aforementioned research have shown that the "gold standard" must be supplemented by cultivation or replaced by the PCR method for toxin gene, but they cannot be independently applied without determining the productive toxin in vivo in a stool sample. This would result in the inability to distinguish carriers from the CDI $(5,8)$. By introducing cultivation and PCR methods in C. difficile diagnostics, technical deficiencies in the production of the "gold standard" mentioned in the introductory part of our work are also avoided. The characteristics of individual PCR tests often show individual high values (up to $100 \%$ ) of sensitivity, specificity, PPV and NPV $(9,10)$. During this study, we applied the abovementioned positions in setting strict criteria for a really positive and negative finding of toxins and GDH C. difficile (see the material and methods), thus avoiding the clinical data and criteria and the possibility that patients in the investigated group were without diarrhea caused by $C$. difficile or that there were patients with CDI in the control group.

Microbiological laboratories use different tests, protocols i.e. CDI diagnostic algorithms in their everyday work. Most of these techniques and methods (GDH, metabolic products (isocaproic acid, etc.), gas liquid chromatography, etc.) are not specific since both 
non-toxic strains of $C$. difficile and some residents of the normal flora of the digestive tract have identical identification products $(2,4,6)$.

A large number of CDI diagnostic tests are available, but it is difficult to choose the right ones and avoid the disadvantages each of them has individually. The control of European laboratories shows that $93 \%$ of local laboratories detect toxins directly in the stool and approximately $80 \%$ use commercial ELISA tests; $41 \%$ of laboratories use both toxins and cultivation $(2,7)$. The variety of tests (ELISA, rapid immunochromatographic tests, PCR techniques, etc.) that are used in everyday work require performance of controls to avoid false positive or negative results. The control can be conducted in two directions: 1 . Testing the reliability of the test individually and/or 2. Within the CDI diagnostic protocol/algorithm using two or more individual tests in order to achieve positive synergy and to eliminate the disadvantages of each of the individual reagents.

Available ELISA, immunochromatographic and latex agglutination tests in the CDI diagnostics have different performances that make them convenient or unsuitable for the daily diagnosis of CDI.

Glutamate dehydrogenase $(\mathrm{GDH})$ is a specific enzyme for all $C$. difficile isolates, and in most studies it has high sensitivity and even better specificity. Result of the meta-analysis of Shetttya et al. (11) showed high linkage of GDH findings with the presence of $C$. difficile in patient samples. The sensitivity and specificity rate was $>90 \%$, which is very close to the results obtained by cultivating on the selective medium. However, it should be kept in mind that this test has a high rate of false positive findings (up to $20 \%$ ) because it detects both nontoxigenic isolates and a large number of other bacterial species that produce this enzyme. It has been found that Clostridium (C.) sporogenes, Peptostreptococcus (P.) anaerobius, Clostridium (C.) botulinumand Bacteroides (B.) asaccharolyticus can give false positive results. Basically, there is a high homology of the GDH gene between $C$. difficile and the aforementioned species (up to 90\%), resulting in C. sporogenes and P. anaerobius producing proteins similar to the biochemical and immunological characteristics of C. difficile proteins and can be detected by commercial GDH cross-reactions. However, the results of the study show that the protein filters of B. asaccharolyticus did not give a cross-reacted latex agglutination test, indicating that there is at least one mechanism for producing false positive results (12).

The use of latex agglutination tests for the detection of GDH in most studies has a sensitivity of up to $70 \%$, but ELISA GDH detection tests show a sen- sitivity of $80-90 \%$ (e.g., GDH EIA (Wampole C. DIFF CHEK-60 Assay, Iver Med, Princeton, (NJ sensitivity $100 \%$, specificity $93.2 \%$, PPV $61.4 \%$, NPV 100\%) (5, 6, 9, 13). Yoldas et al. (8) indicates that by 2010 the sensitivity of latex agglutination tests for GDH was about 58-68 \%, specificity 94-98\% (e.g., C. DIFF CHEK-60 Techlab Inc., Blackburg, Va, (sensitivity 100\%, specificity 75\%, PPV $21.4 \%$, NPV 100\%).

All researchers agree that high sensitivity values, even more negative predictive rule values, low cost, short time and simple performance make GDH tests a powerful reagent especially when combined with another toxin test within two or three steps of the CDI diagnosis algorithm $(5,6,8,11,13)$. The high values of the characteristic of the tests used to detect GDH in our study, despite a small sample, are confirmed by previous attitudes.

Tests that detect only GDH or in combination with toxin $\mathrm{A}$ have better performance but do not distinguish all toxigenic (eg A-B + strains of $C$. difficile) from non-toxigenic strains in relation to individual toxin A immunoassays. A particular problem in GDHdetecting tests is that their positivity does not indicate $\mathrm{CDI}$, although the patient has diarrhea or symptoms produced by the gastrointestinal tract (GIT). However, it should be noted that the standard cytotoxin test B detects up to $90 \%$ of CDI clusters (6).

Evidence of produced toxins in patients' samples is a key procedure in CDI diagnosis. There is a large number of tests that detect individual or both toxins at the same time. In general, all tests that detect only one $C$. difficile (A or B) toxin have lower sensitivity but also high specificity compared to other assays and standards (detection of only one toxin by immunochromatographic tests is less reliable than conventional ELISA (period up to 2010 , most of them up to $80 \%$ a year) $(6,7$, 10). In contrast, some researchers reported that individual immunochromatographic tests (eg Color pac Toxin A C. difficile test, Becton Dickinson, USA, sensitivity up to $89 \%$ ) were as good as ELISA (5).

Tests that detected both toxins (individually or both at the same time) were more reliable. In general, the results obtained indicate that the detection of both toxins by one test takes precedence over tests that only detect toxin A (performance values, above all specificity, of the tests were over $90 \%$ (eg C. diff Toxin A + B, Diagnostic Automation Inc., Calabasas, CA, USA; Cytoclone A/B Meridian Diagnostic, Cincinnati, Ohio; Remel prospect C. difficile toxin $\mathrm{AB}$, Microplate, Lenexa, $\mathrm{KS})(6,8,9)$.

The detection of both toxins avoids both concerns about strains that produce only toxin B or just toxin A. 
The best example is the study of Shina et al. (14) which compares the characteristics of VIDAS C. difficile Toxin A\& B assay (CDAB) (BioMerieux, France) and VIDAS C. difficile Toxin A II assay (CDA) (BioMerieux, France). The sensitivity of VIDAS CDAB was twice as high as VIDAS CDA $(65.3 \%$ vs. $29.8 \%)$. The specificity of the analyzed tests was similar (93.8\% to 94.5\%). However, the VIDAS $\mathrm{CDAB}$ assay revealed more tcdA $(+) \mathrm{tcdB}(+)(60 \%$ to $45.3 \%)$ as well as tcd A (-) tcdB (+) strains (70.7\% to $0 \%)$.

Reliability of toxin immunoassays can be enhanced by modifying the criteria for interpretation in the domain of equivocal findings (eg, the sensitivity of conventional ELISA RIDASCREEN Clostridium difficile TOX AB, R-Biopharm AG, Darmstadt, Germany test shows an increase of $10 \%$, without major changes in specificity values). However, despite this modification in the criteria, the sensitivity is low and the tested ELISA assays are not entirely accurate in detecting $C$. difficile toxins (5).

The reasons for the unreliability of the toxin detection tests should be sought in the event of a poor design of the test. A false positive finding of toxin A and $B$ can be a consequence of a cross-reacted antibody response to non- $C$. difficile-based antigens (for example, it may be possible, in combination tests, due to a factory error, that the reagent contains, in addition to antibodies, toxins and components that detect GDH, which is the reason for a false positive reaction: eg. Culturette Brand Rapid Latex Test, Marion Scientific, Marion Laboratories, Inc., Kansas City, Mo.) (12). It is less likely that the crossed reaction is due to contamination during ELISA testing - a step of washing the pool or another step, which depends on the type of ELISA test. It must be also considered which type of monoclonal antibody contains a test used to interpret the results. A false negative finding of toxin can be due to instability of the strain in the amount of toxin produced, the inactivation of toxins due to temperature changes, the activation of toxin-disrupting proteases, the presence of inhibitors in the sample, and inadequate laboratory procedures $(5,9$, 12). In the study of Shin et al. (7), it has been confirmed that a false negative toxin finding may be associated with a small number of colonies of $C$. difficile isolates (semi-quantitative diagnosis), which reflects a smaller amount of the produced toxin that is degraded by proteases or is blocked by inhibitors. Freezing of the sample can also influence the reliability of the findings. According to some studies (9), freezing has little effect on immunoblot methods and latex agglutination, but can therefore affect the sensitivity of the PCR method and its decrease from $100 \%$ to $74 \%$. Probably, the DNA is acting differently on freezing against antigens.

The results of the research carried out in Niš howed high values of the characteristic for certain toxindetecting tests in feces (sensitivity up to $88 \%$, specificity up to $98 \%$, etc.) (Table 1 and 2). Such high values have been recorded in some of the abovementioned studies (5), but in most cases they are lower by $10-20 \%$. The reasons for relatively high values should be sought in strict selection criteria for samples that are close to criteria present in factory conditions when designing such tests. We believe that in the daily work the values of the characteristics of the tested tests would be lower. Analysis of the results of the research conducted in Nis and of other researchers $(2,5,6,10)$ show that there is a need for a new generation of individual, fast, sensitive diagnostic tests, which should give reliable results after 15 minutes of sampling. The fast immunochromatographic tests that are currently in use give priority to ease of performance, internal control (an integral part of each test procedure) which prevents the number of samples to be a burden on medical personnel, enabling thus visual readings (compared to conventional ELISA tests). However, the difficulties in interpreting the color intensity of positive findings lead to a fall in sensitivity, which can be partially corrected by re-testing, but with an increase in costs. Fast commercial immunochromatographic tests are more suitable for laboratories where individual tests are performed or if reference methods are not available (PCR, cell cytotoxicity test, etc.). The following characteristics should be taken into account when deciding on the mode of testing and the test: detection of GDH or toxin, combined test, availability, limiting circumstances (eg. execution time, lower limit of GDH or toxin detection values (cut-off values), difficulty in interpreting, suitability for individual tests, etc.), equipment and laboratory load. Price is also a significant factor, but a reliable test does not require re-testing and consequently higher costs.

Preliminary studies have shown variations in the characteristics of the tests used in the CDI diagnostics. These disagreements in findings are due to different modalities of laboratory conditions, staff, patient populations and the geographical diversity of $C$. difficile isolates. It is therefore necessary to design and test the reliability of the reagents in the plant for as many isolates from different geographical areas, countries and continents (9). In order to improve the microbiological diagnosis of CDI in day-to-day work, different laboratory algorithms can be used. By combining different 
tests, the disadvantages of the test can be avoided, and the synergy of good characteristics will lead to an accurate diagnosis.

Microbiological laboratories use a single step in the diagnosis of CDI (determination of toxins A and B). This algorithm directly depend on the characteristics of the used test and can have low values of sensitivity, specificity, PPV, NPV.

In practice, the algorithms of two, three or more steps are more commonly used. Most researchers agree that due to high sensitivity, specificity and NPV values, the GDH test is the best first step (6-8).

The use of GDH in a two-strand algorithm, together with a confirmatory test (for produced toxins or PCR for toxin gene), is an acceptable strategy. A negative finding by the GDH test confirms the CDI negative diagnosis, however, a positive $\mathrm{GDH}$ finding requires in the second step a confirmation test of the produced toxin or token-encoding genes. This is best confirmed with the PCR method in the stool and isolate. In the research by Fenner et al. (15), out of $187 \mathrm{GDH}$ positive stool samples $69(37 \%)$ were positive for toxins. In the group of negative GDH, 10 patients had a toxin-positive result, of which five were confirmed positive by the PCR method. In $52.9 \% \mathrm{GDH}$ and toxin-positive patients, a growth of C. difficile colonies was found. Similar information was published by Goldenberg et al. (16) by using the twostep algorithm (GDH $\rightarrow$ PCR (tcdB)), by means of which a higher percentage of confirmed CDI diagnosis was obtained compared to the ELISA test for toxin detection (higher by 55\%)(EIA Clostridium difficile AB kit, Meridian Premier Inc., Cincinnati, USA), with the characteristics of the algorithm being: sensitivity 94\%, specificity 99\%, PPV 94\% and NPV 99\%.

Interpretation of combined panel tests (detected simultaneously by GDH and toxin) is more complicated because the combination of positive GDH and negative toxin has to be further considered and investigated using a reference test (PCR or cytotoxicity test on cell culture, test for determining the production of toxins in liquid culture) (6). On the other hand, the positive finding of $\mathrm{GDH}$ and toxin $\mathrm{A}$ or $\mathrm{AB}$ confirms the diagnosis of $\mathrm{CDI}$, while the negative finding of $\mathrm{GDH}$ and toxin $\mathrm{A}$ or $\mathrm{AB}$ excludes the CDI diagnosis. Most of the combined tests have high sensitivity in the detection of GDH (90\%) and low specificity (up to $80 \%$ ), whereas in the detection of toxins, the sensitivity is up to $80 \%$ and specificity is up to $97 \%$ (5).

In the research of Brown and al.(9) using a diagnostic algorithm, test performance (GDH EIA-Wampole C. DIFF CHEK-60 Assay, Iver Med, Princeton, NJ; C. difficile Toxin AB EIA -Remel prospect; $C$. difficile toxin $\mathrm{AB}$, Microplate, Lenexa, $\mathrm{KS}$ ) was better than their individual testing. Using algorithms, the reliability of the CDI diagnostics improves by $10 \%$ because it excludes some false positive and false negative results $(83 \%$ sensitivity, 100\% specificity, PPV 100\%, NPV 98.2\%). Using the three-step algorithm $(\mathrm{GDH} \rightarrow$ toxin EIA tox $\mathrm{AB} \rightarrow \mathrm{PCR}$ ), even better results are obtained (sensitivity $92 \%$, specificity $100 \%$, PPV 100\%, NPV 99.1\%). If PCR is used as a third step, then fresh samples should be used, in the case of which the sensitivity is $100 \%$.

In the study of Shina et al. (8) by testing the threestep algorithm (VIDAS CDAB -ELFA (immunofluorescence test) (BioMerieux, ME, France) $\rightarrow$ bacterial culture on selective substrate $\rightarrow$ produced toxin in bacterial culture) the obtained reliability values (sensitivity $84.8 \%$, specificity $91.4 \%$, PPV 95.5\%, NPV $100 \%$ ) were by $19 \%$ better than the VIDAS CDAB ELFA test. The results of this study have shown that the twostep algorithm (VIDAS CDAB-ELFA $\rightarrow$ bacterial culture on the selective medium) does not lag behind the algorithm GDH $\rightarrow$,gold standard, (cytotoxicity test on cell culture). The use of cultivation has shown that $31 \%$ of CDI cases would be lost if relying only on one step in diagnosis (detection of the produced toxin in the sample, in the domain of false negative or equivalence values of the test). Based on these results, it has been shown that equivalence findings in the detection of produced toxins, while cultivating $C$. difficile isolates, confirm the CDI diagnosis, which is also confirmed by the PCR method.

Using the three-step algorithm (toxin detection in the fecal samples $\rightarrow$ cultivation of all samples (toxin positive and toxin negative) on the selective agar $\rightarrow$ determining the presence of toxins in the liquid culture of the isolate $C$. difficile), in the Public Health Institute Niš, a much larger number of cases with microbiological diagnosis of CDI was obtained (by 20-30 \%, depending on the test used). This protocol also explains the equivocal and minor number of false-negative findings of the presence of toxins in the samples (17).

Algorithms of two or three steps in the CDI diagnostics increase the cost but give more credible results.

In the diagnosis of CDI, the relationship between laboratory findings and clinical diagnosis is not always completely clear. Several pre-analytical factors (eg fecal sampling conditions, sample retention time prior to testing and arrival in the laboratory, etc.) can significantly influence the diagnosis (18). Finally, to set the diagnosis of CDI, but not less important, is the 
attitude of a clinician in the individual examination of patients. In the research of Vanpoucke H. et al. (5), the presence of psudomembranous colitis in one patient with endoscopic methods was determined, but the cultivation tests, the cytotoxic essay and the commercial essay of the presence of toxins were negative, except one. In the second patient with a CDI examination of three fecal samples obtained at short intervals, all samples were culture and PCR positive (A + B + strain). The cytotoxic effect was confirmed after incubation for 24 hours in the first sample, after $48 \mathrm{~h}$ in the second, but the third one remained negative. Also, CDI empirical therapy usually begins prior to laboratory confirmation and even some doctors continue with the therapy despite negative results. It should be noted that a significant number of moderate CDI cases persist after the suspension of the use of antibiotics that preceded the $\mathrm{CDI}$ and consequent reduction in dietary carbohydrate. A positive finding of rapid tests for $C$. difficile toxins can lead to therapy without providing the possibility of spontaneous withdrawal of symptoms $(19,20)$.

\section{CONCLUSION}

Although the results of this study confirm that there is no ideal diagnostic test or algorithm in the microbiological diagnosis of CDI, high sensitivity, specificity, PPV and NPV make GDH tests suitable for the first screening of stool samples in everyday work. High sensitivity and specificity values of Rida ${ }^{\circledR}$ QUICKC. difficile Toxin A/B (R-Biopharm AG, Darmstadt, Germany), ImmunoCard ${ }^{\circledR}$ C. difficile TOXIN A\&B (Meridian Bioscience Inc., Cincinnati, USA) and ELISARidascreen C. difficile Toxin A/B (R-Biopharm AG, Darmstadt, Germany) recommend these tests for everyday laboratory work, but with the need of checking the reference method and examining the patients individually, with the cooperation of a clinician. Despite the disadvantages, the possibility of obtaining the findings on the same day, successful screening of negative results and use in each laboratory makes fast tests necessary in everyday work.

\section{Acknowledgments}

This work was supported by the Ministry of Education, Science and Technological Development of Serbia [Projects No. 172061]

\section{Conflict of interest}

The authors declare that they have no conflict of interest. 


\section{References}

1. Takahashi M, Mori N, Bito S. Multi-institution case-control and cohort study of risk factors for the development and mortality of Clostridium difficile infections in Japan. BMJ Open 2014; 34:1-9.

https://doi.org/10.1136/bmjopen-2014-005665

2. CrobachMJ, Planche T, Eckert $C$, et al. European Society of Clinical Microbiology and Infectious Diseases: update of the diagnostic guidance document for Clostridium difficile infection. Clin Microbiol Infect 2016; 22 Suppl 4:S63-81.

https://doi.org/10.1016/j.cmi.2016.03.010

3. Kuijper EJ, Coignard B, Tull P. Emergence of Clostridium difficile-associated disease in North America and Europe. Clin Microbiol Infec 2006; 12:218.

\section{https://doi.org/10.1111/j.1469-0691.2006.01580.x}

4. Gupta A, Cifu AS, Khanna S. Diagnosis and Treatment of Clostridium difficile Infection. JAMA 201811; 320:1031-3.

\section{https://doi.org/10.1001/jama.2018.12194}

5. Vanpoucke H, Baere T, Claeys G, et al. Evaluation of six commercial assays for the rapid detection of Clostridium difficile toxin and/or antigen in stool specimens. Clin Microbiol Infec 2001; 2: 55-64. https://doi.org/10.1046/j.1469-0691.2001.00141.x

6. Turgeon D, Novicki T, Quick J, et al. Six rapid test for direct detection of Clostridium difficile and its toxins in fecal samples compared with the fibroblast cytotoxicity assay. J Clin Microbiol 2003; 1:667-70. https://doi.org/10.1128/JCM.41.2.667-670.2003

7. Shin BM, Kuak EY, Lee EJ, Songer G. Algorithm combining toxin immunoassay and stool culture for diagnosis of Clostridium difficile infection. J Clin Microbiol 2009; 47:2952-6.

https://doi.org/10.1128/JCM.00609-09
8. Yoldas $\mathrm{O}$, Altandis $\mathrm{M}, \mathrm{Cufar} \mathrm{D}$, et al. A diagnostic algorithm for the detection of Clostridium difficileassociated diarrhea. Balkan Med J 2016; 33: 80-6.

https://doi.org/10.5152/balkanmedj.2015.15159

9. Brown NA, LeBar WD, Young CL, et al. Diagnosis of Clostridium difficile infection: comparasion of four methods on specimens collected in Cary/Blair transport medium and tcdB PCR on fresh versus frozen samples. Infectious disease reports 2011; 3:159.

https://doi.org/10.4081/idr.2011.2331

10. Eigner U, Fenner I, Veldenzer A, et al. Evaluation of six PCR assays in combination with patient related data for the diagnosis of Clostridium difficileassociated infections. Clin Lab 2014; 60:1343-50. https://doi.org/10.7754/Clin.Lab.2013.130735

11. Shetty N, Wren MW, Coen PG. The role of glutamate dehydrogenase for the detection of Clostridium difficile in faecal samples: a meta-analysis. J Hosp Infect 2011;77(1):1-6.

https://doi.org/10.1016/j.jhin.2010.07.024

12. Lyerly DM, Ball DW, Toth J, Wilkins T D. Characterization of cross-reactive proteins detected by Culturette Brand Rapid Latex Test for Clostridium difficile. J Clin Microbiol 1988; 26:397-400.

13. Staneck JL, Weckbach LS, Allen SD, et al. Multicenter evaluation of four methods for Clostridium difficile detection: ImmunoCardC. difficile, cytotoxin assay, culture, and latex agglutination. J Clin Microbiol 1996; 34:2718-21.

14. Shin BM, Lee EJ, Kuak EY, Yoo SJ. Comparison of VIDAS CDAB and CDA immunoassay for the detection of Clostridium difficile in a tcdA- tcdB+C. difficile prevalent area. Anaerobe 2009; 15:266-9. https://doi.org/10.1016/j.anaerobe.2009.09.008 
15. Fenner L, Widmer AF, Goy G, et al. Rapid and reliable diagnostic algorithm for detection of Clostridium difficile. J Clin Microbiol 2008; 46:328-30. https://doi.org/10.1128/JCM.01503-07

16. Goldenberg SD, Cliff PR, Smith S, et al. Two-step glutamate dehydrogenase antigen real-time polymerase chain reaction assay for detection of toxigenic Clostridium difficile. J Hosp Infect 2010; 74:48-54.

https://doi.org/10.1016/j.jhin.2009.08.014

17. Stojanovic P. "Role of Clostridium difficile in pathogenesis of the disease in intestinal tract, Doctoral dissertation, University of Nis, Faculty of Medicine, 2010.
18. Weese JS, Staempfli HR, Prescott JF. Survival of Clostridium difficile and its toxins in equine feces: implications for diagnostic test selection and interpretation. J Vet Diagn Invest 2000; 12:332-6. https://doi.org/10.1177/104063870001200406

19. Högenauer C, Hammer HF, Krejs GJ, Reisinger EC. Mechanisms and management of antibioticassociated diarrhea. Clin Infect Dis 1998; 27:702-10. https://doi.org/10.1086/514958

20. El-Gammal A, Scotto V, Malik S, et al. Evaluation of the clinical usefulness of $C$. difficile toxin testing in hospitalized patients with diarrhea. DiagnMicrobiol Infect Dis 2000; 36:169-73.

https://doi.org/10.1016/S0732-8893(99)00129-7 


\title{
Pouzdanost mikrobioloških testova u dijagnostici infekcija izazvanih bakterijom Clostridium Difficile
}

\author{
Predrag Stojanović1,2, Niko Radulović3 ${ }^{3}$ Kocić Branislava ${ }^{1}$, Dinić Marina ${ }^{1,2}$, \\ Biljana Miljković-Selimović ${ }^{1}$, Kristina Stojanović ${ }^{1}$ \\ ${ }^{1}$ Univerzitet u Nišu, Medicinski fakultet, Niš, Srbija \\ ${ }^{2}$ Institut za javno zdravlje Niš, Centar za Mikrobiologiju, Nacionalna referentna laboratorija za \\ anaerobne infekcije - Clostridium difficile, Niš, Srbija \\ ${ }^{3}$ Univerzitet u Nišu, Prirodno-matematički fakultet, Departman za hemiju, Niš, Srbija
}

\section{SAŽETAK}

Ispitivanje karakteristika (senzitivnost, specifičnost, pozitivna prediktivna vrednost (PPV), negativna prediktivna vrednost (NPV) i verodostojnost) testova za mikrobiološku dijagnostiku infekcija izazvanih bakterijom Clostridium (C. difficile).

Istraživanje je urađeno u Institutu za javno zdravlje Niš, Centru za mikrobiologiju tokom perioda 2016 2019. godina. Istraživanjem je obuhvaćeno 25 bolesnika sa CDI ( 25 uzoraka fecesa) i 50 bolesnika sa dijarejom kod kojih nije postavljena dijagnoza CDI (50 uzorka fecesa). Uzorci su pregledani različitim testovima za otkrivanje toksina u stolici. Takođe su korišćena dva testa za dokazivanje produkovanog enzima glutamat dehidrogenaze GDH. Kao referentni test korišćen je RIDA GENE Clostridium difficile test (Real time multiplex PCR, R - Biofarm, Damstadt, Germany).

Među ispitivanim testovima najveću senzitivnost $\mathbf{u}$ otkrivanju toksina imao je ELISA- Ridascreen $C$. difficile Toxin A/B (R - Biopharm AG, Darmstadt, Germany) (88\%; PPV = 85,71\%; NPV = 97,87\%) a najmanju $C$. difficile TOXIN A \& B CHEK1 (VEDALAB, ALENCON CEDEX, France) $(68 \%$, PPV = 85\%; NPV = 85,45\%). Svi testovi za otkrivanje toksina, imali su visoku specifičnost koja nije bila manja od $92 \%$. U otkrivanju antigena GDH bolje karakteristike pokazao je test Rida ${ }^{\circledR}$ QUICK C. difficile GDH (R - Biopharm AG, Darmstadt, Germany) (senzitivnost $100 \%$; specifičnost $92 \%$; PPV $=89,28 \%$; NPV $=100 \%$ i verodostojnost $94,66 \%$ ).

Rezultati istraživanja sprovedenog u Nišu pokazali su visoke vrednosti parametara za pojedine testove koji detektuju toksine u fecesu (senzitivnost do $88 \%$; specifičnost do $98 \%$, itd.). Rezultati istraživanja u drugim studijama pokazuju da su vrednosti parametara koje određuju karakteristike testova manje za $10 \%-20 \%$, mada ima i studija čiji su rezultati saglasni našim. Razloge za relativno visoke vrednosti treba tražiti u strogim kriterijumima selekcije uzoraka koji su bliski kriterijumima koji se sprovode u fabričkim uslovima prilikom dizajniranja testova.

Iako rezultati i ovog istraživanja potvrđuju da nema idealnog dijagnostičkog testa u mikrobiološkoj dijagnozi CDI, visoke vrednosti senzitivnosti, specifičnosti, PPV i NPV čine GDH testove pogodnim za prvi skrining pregled uzoraka stolice u svakodnevnom radu.

Ključne reči: Clostridium difficile, toksin, glutamat defidrogenaza (GDH), mikrobiološka dijagnoza 